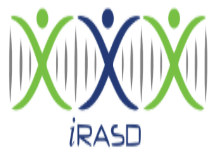

iRASD Journal of Management

Volume 4, Number 1, 2022, Pages 26 - 37

\title{
Identifying the Demand-Based Financial Issues in the Agriculture Sector of Pakistan: A Qualitative Thematic Analysis
}

\author{
Tahir Mahmood ${ }^{1}$, Noman Arshed ${ }^{2}$ \\ ${ }^{1}$ University of Management and Technology Lahore, Pakistan. Email: tahirchishtyi@gmail.com \\ ${ }^{2}$ Lecturer, Department of Economics, University of Management and Technology Lahore, Pakistan. \\ Email: noman.arshed@umt.edu.pk
}

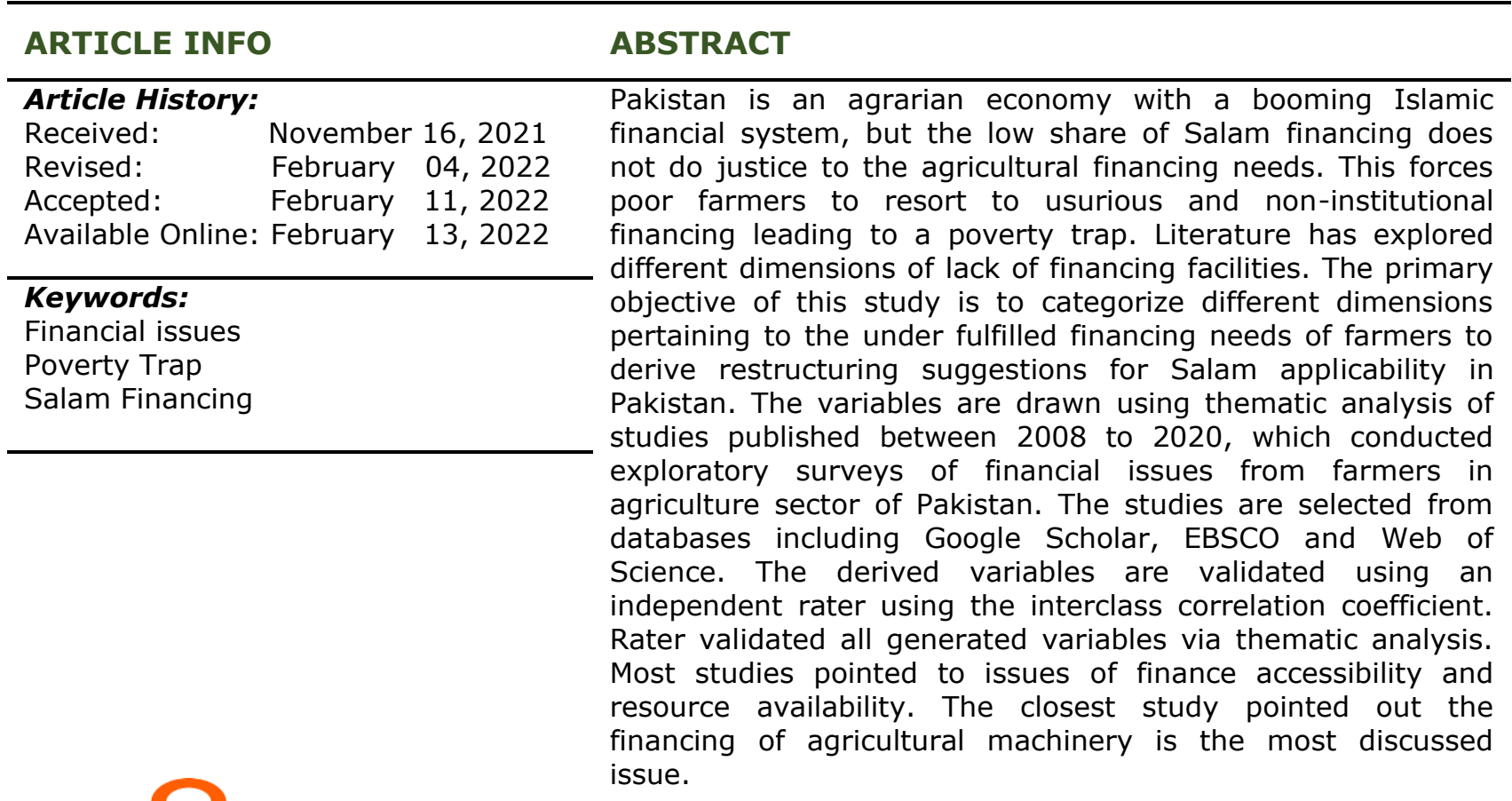
article under the Creative Common Attribution Non-Commercial 4.0

Corresponding Author's Email: noman.arshed@umt.edu.pk

\section{Introduction}

The agriculture sector is Pakistan's largest growth contributing sector and affects rural economic conditions. Pakistan was an economically strong agrarian economy (Government of Pakistan, 2019). The agriculture sector of Pakistan has contributed to GDP is approximately $18.5 \%$. The study of (Abdullah et al., 2015) stated that Pakistan has a large potential for water resources and irrigation systems, including river and canal systems. This system is providing the impetus to the agriculture sector. It creates $38.5 \%$ of jobs and is the largest source of foreign exchange. The agriculture sector $65.5 \%$ of exports from countries, excluding the export of leather. According to PES (2017-2018), the agriculture sector productivity was highly affected, leading to no new employment generation. According to (Food and Agriculture Organization, 2016), Pakistan ranked top $13^{\text {th }}$ in rice production and is the top ten producers of cotton, wheat and fruits like citrus, mangoes, sugarcane, and dates.

The Government of Pakistan (2017) states that 57\% population of Pakistan live less than US $\$ 2$ per day, of which $26.46 \%$ are facing extreme poverty. It is stated that the agriculture sector is giving products around $50 \%$ below the level to its potential. SBP Annual Report (2021) shows the agriculture sector has been facing stress for the last few years. World Bank Group (2019) coined the major reason for these issues, they indicated that around $80 \%$ of the Pakistani population was unbanked, and farmers avoided the credit 
schemes. This behavior is restricting the agriculture sector to achieve its fullest. Other neighboring countries are also facing similar problems in the provision of acceptable and accessible credit schemes (S. M. Kumar, 2013).

According to Zaidi (2005), Pakistan's agriculture sector was booming in the green revolution that started in the 1960s. When Pakistan was made its first plan, between 19481953, its agriculture sector was weak and had poor infrastructure. In 1952, the Government of Pakistan imported 1 million tons of wheat because of its shortage. Since then, the government has realized the importance of a sustainable agriculture sector and included agricultural development in its plans. Because of economic instability, there were no major improvements in the first five years (1955-160) plan for the agriculture sector. In the next five-year plan (1960-1965), the government fully supported the agriculture sector leading to the green/grain revolution. In this era, grain production was raised by $27 \%$. In the next five-year plan (1965-1970), the government increased the latest machinery, water availability, improved seeds and fertilizers. But the 1970s to 2007 agriculture sector was not able to show progress like the green revolution era.

This turmoil has affected the lives of the farmers and the sustainability of foodrelated supply chains leading to food insecurity. The long gestation periods of the crops usually absorb the farmer's capital. The poor countries are not fully able to utilize the resources. People living in rural areas are stuck in the poverty trap and struggle to pay off the unending loans, bad health facilities, variable crop productivity and lack of education. In a developing country like Pakistan, the provision of credit may ensure the utilization of high quality and timed inputs and help sort the provision of resources.

This credit can be categorized into four types, i.e., production, investment, marketing and consumption (Khan \& Nomani, 2021). The modernization and advancement of agriculture are not possible without financing availability. This financing can develop the economic environment, which helps transition the traditional agriculture sector to the advanced and mechanized agriculture sector (Abdulquadri \& Mohammed, 2012; Sims \& Kienzle, 2016).

Since all crops have different requirements, a generalized product of financing provided by the conventional financial system may not suffice the modern needs. Different crops cultivate in different weather and take different times to grow and harvest like wheat takes approximately 165 days, rice-1509 takes 90 days, and Maze takes 100 to 120 days. Further, they all have different supply chain requirements in order to extract the maximum out of them. Adams and Hunter (2019) describe the agriculture sector provides different food crops (wheat, rice, bajra, jawar, maize, barley, and cotton), livestock items (milk, beef, mutton, poultry meat, and fats) and fruits (citrus, mango, apple, and banana) and also employs rural and urban population. Its improvement helps in achieving food security.

According to Zuberi (1989), Iqbal et al. (2003), Saleem and Jan (2011) and Chandio et al. (2016), the availability of timely finance and flow of money from rich to weak sector makes new door of the economy and make new economic activities. It creates new jobs, increases the production process, increases exports, makes new industries and infrastructure, decreases poverty, and starts welfare programmers. Similarly, it improves the lifestyle of individuals involved in agricultural production leading to growth (Kaleem \& Ahmad, 2016).

According to the study of Iqbal et al. (2015), in 2014 and 2015 agriculture sector contributed $20.9 \%$ and employment $43.5 \%$. But unavailability of credit facilities creates a problem to purchase machinery, negatively affecting the agriculture sector. Availability of agriculture financing assuring the agriculture sector development and increases in the agriculture production (Hashmi et al., 2015; Khaliq et al., 2016).

There are three major players involved in agriculture credit in Pakistan. First is the government institutions like ZTBL (Zarai Tariqati Bank of Pakistan Ltd), second is the conventional banking system, and third is the Middle man ("Arthi"). These players do not provide the Shari'ah-compliant facilities to the farmer and charge interest against providing credit facilities to the farmer. The conventional system's current usurious arrangement is 
least interested in how and when the financing is utilized, rather creditworthiness is the client (Khan \& Nomani, 2021; A. Kumar et al., 2010). This arrangement requires the collateral, whose unavailability may rule out many viable projects (Dhumale \& Sapcanin, 1998).

While the risk-sharing and riba free mechanism (Saeed et al., 2013) of Islamic finance have more acceptability among farmers in Islamic countries (Yazdani \& Hill, 1993), it also have a higher recovery rate (M. Ahmed \& Roy, 1995).

Currently, interest-free schemes are scarce. Most interest-based credit schemes are available to the farmers. This interest-based systems contribute to developing the poverty trap, where farmers are highly vulnerable to bankruptcy in any climate related uncertainty, considering Pakistan is the most vulnerable (Fahad \& Wang, 2020). In the case of India, farmers are stressed due to a lack of credit facilities and low prices of crops. The ratio of suicide is increased in India; nearly 18,000 Indian farmers are committing suicide every year (National Crime Records Bureau of India).

Islam has provided Salam financing as an alternative to conventional financing, emphasizing the freedom from the usurious system and promoting productivity. Several studies have provided the models of Salam with their merits to the agriculture sector (Kaleem \& Wajid, 2009). But according to Kaleem and Ahmad (2016), by 2002, only 3 to 5 percent of the lending is extended to the rural areas. Currently, Islamic banking bulletin of June 2021 reports only 2.1 percent of total Islamic financing is allocated for Salam, and only 1.2 percent of Islamic financing is for agriculture sector, whereas the overall banking sector is directing 4.0 percent of financing to agriculture sector (SBP, 2021). This shows that despite having a specialized product for agri-financing, Islamic banking cannot penetrate the as an alternative to the conventional or informal financing system.

Many studies have been conducted on assessing reasons restricting the demand for Salam financing, but they lack the categorization of the issues faced by the demanders of Salam financing. This study explores the literature that has conducted the farmers' survey regarding issues related to access to finance and conducts a thematic analysis to draw down major variables defining the demand for Salam financing.

\section{Literature Review}

Several empirical studies have explored the issues faced by farmers in achieving higher agriculture productivity. Most of the problems discussed converge to the affordability and availability of financial resources in developing countries.

The study of Uddin (2008) explored the Bangladeshi agrarian rural region. Their main problem was $40 \%$ poverty. People face a lack of proper medical facilities, education, and training programs that may help to boost the economy. The Islami Bank Bangladesh provides a scheme for rural development to facilitate improvement in educational level, introducing the housing loans for infrastructure helps build shelters, homes and tubewell and overcome the other financial issues. This study collected data from 50 people with specific socio-economic backgrounds through interviews.

Studies have compared the evils of non-institutional / informal credit facilities which farmers avail (Iftikhar \& Mahmood, 2017). While for Pakistan, most of the credit is availed for consumption purposes, farmers tend to leverage their assets (mostly land) (Shabir et al., 2020). Further, informal credit is also compounding irrespective of the outcome of credit utilization, and it is also usurious.

Shabir et al. (2020) stated that in current decades, the financing needs of farmers have increased, the reason behind this reconstructing the agriculture sector. Financing availability is an important factor in increasing farmers' production and profits. This study sees the impact of credit in the production process in the Sargodha district. Primary data were collected from 8 villages in the Sargodha district in 2018. The four zone were established from each zone 2 villages were selected. The sample size was 160 farmers. The results show a significant positive effect of financing on wheat production. The farmer utilizes the $30 \%$ loan to fulfil the inputs needs like purchasing fertilizers and seed, and the 
remaining $70 \%$ are for consumption purposes like marriage, purchasing or leasing farmland or buying machinery like tractors.

The study of Ahmed et al. (2018) explained many factors limiting the farmer's capacity and capability, like shortage of water facilities, poor contribution of government or lack of government interest in the agriculture sector, old technology and lack of education and training. But the lack of financing facility is the most sensitive problem the farmer faces, leading to the underachievement of performance and welfare. The current financing facilities is exploitative, interest-based, and have restrictive procedural requirement. The primary data were collected through a questionnaire and used the expert sample method. The total sample size is 40 experts choosing from scholars, bankers, farmers and politicians. The gathered information collected by the farmer was chosen all over Pakistan. According to them, Salam is easy to employ and free from conventional evils like Riba factor and exploitation of farmers.

Islamic finance has provided a Salam financing model specifically designed to finance farming needs. Arshed et al. (2020) stated that Islamic financing could reduce the cost of micro and macro level projects. The adaptation of Shari'ah compliant financing increases the risk shared by the financial sector but integrates the returns of financing with returns of deposits, thus ultimately leading to social prosperity. They compared different financial products in terms of their effect on economic growth and showed the positive effect of Salam financing on growth.

The technology could help in providing opportunities for the farmers. According to Kirui et al. (2013), the inaccessibility of mobile-based phone applications used for money transfer in rural agriculture areas. This study pointed out that access to technology can improve agricultural productivity in Kenya. The data was collected cross sectional from 3 provinces of Kenya and showed that technology had significantly increased annual income by $\$ 224$ per month by resolving the market failure issues faced by the farmer.

According to the study of Lakshmi and Corbett (2020), the current issue in the agriculture sector was food security and climate change deploying artificial intelligence (AI) technology. This study was used thematic analysis to check the AI benefits were linked to understand the objectives to motivate the adoption, lack of its impacts and fulfil the gap between AI agriculture sector and themes related to the energetic capabilities. The result shows that AI is effectively applied to improve productivity and efficiency, discuss the shortage of labor, and show the sustainability of the environment. To improve the agriculture sector obviously, farmers need good technology to improve land fertility, which requires priority financing by the government.

The study of Braun and Clark (2006) explained that thematic analysis is beneficial and easy to imply in studies because the thematic coding is flexible and compatible with different theoretical and epistemological stand points. In thematic analysis, firstly, the short coded themes from the whole data and then coded themes identified in the method used, e.g., semi structured interviews. The study of Christensen and Knight (2014) used thematic analysis to identify themes in the nursing industry. The study of Simon and Hansson (2019) used thematic analysis on 21 semi structured deep interviews from Swedish experts. Asmy et al. (2020) study consisted of WebMoti hardware and software robot systems to facilitate students who have not attended the class regularly. This study also used thematic analysis because WebMoti hardware used video data and video data to generate themes. The researcher established six main themes and four modifiers of these four themes. This study used 2 independent raters for rating the $20 \%$ of video data, which was validated significantly.

The study of Balzani and Hanlon (2020) explained the recent phenomena of farm animal welfare (FAW). The availability of finance or capital is required to improve and maintain the FAW. The 30-year semi systematic review answered two main questions. "What do farmers think (farmer's general view) about farm animal welfare?" and "What are the factors that influence their thinking?". Thematic analysis was used in this study to identify the reasons behind the innovation of FAW. This study suggested strategies including tools to support behavioural changes amongst farmers. The researcher finds 15 
external factors, which affects the FAW, the more influencing factors are economic advantages, communication, time and labor. But farmers can take advantage only when financing facilities are available on time and easily access able.

The study of Vadlamudi (2019) used thematic analysis to explain agriculture sector challenges. This study explored the problem that farmers had utilized traditional cultivation methods and lack of financing facilities. This study is proposed that artificial intelligence can help meet the requirement of food and sustainability. The text mining of articles from 20142019 for major countries showed that AI could increase productivity and efficiency and secondarily to address labour shortages and environmental sustainability concerns.

Literature has defined the financial issues related to agriculture. It has three major categories, i.e. access, utilization and payback. In our case, the agriculture sector examines the actual issues faced by the farmer regarding finance.

The farmer needs finance to fulfil his financial needs, if farmers have finance, they will grow crops and fulfil his inputs and other requirement. Finance facilitates the farmer whole process of growing and selling the crops. There are two major sources of finance. Financing could be done using equity or debt, but farmers do not have equity since Pakistan is a developing country with high rural poverty. Hence the debt is usually acquired using intuitional/formal or informal methods.

In the case of the agriculture sector of Pakistan, farmers obtain loans from institutional or non-institutional, both charge interest rates and require security in the form of pledging the land or other property. Considering that Pakistan is more than $90 \%$ Muslim, this structure is not permissible Islam. This is the origin of a wide array of problems that this study intends to explore.

\section{Data and Methodology}

This qualitative data of 13 empirical survey studies related to agricultural financing issues was collected from the years 2008 to 2020. The data is collected using the three different main databases, including Google Scholar, EBSCO, and Web of Sciences. This study was used qualitative content analysis to generate the themes based on financial issues and their consequences. Since this study is intended to explore the productionrelated issues that the farmers are facing specifically linked to the cost and financing, the selected studies are primarily using a questionnaire to assess the financial issues regarding the agriculture sector of Pakistan. Table 1 shows the selected articles for analysis that fulfil the selection criteria provided in figure 1 . The codes for the studies are also mentioned in the table in $4^{\text {th }}$ column which are used to address the studies later on.

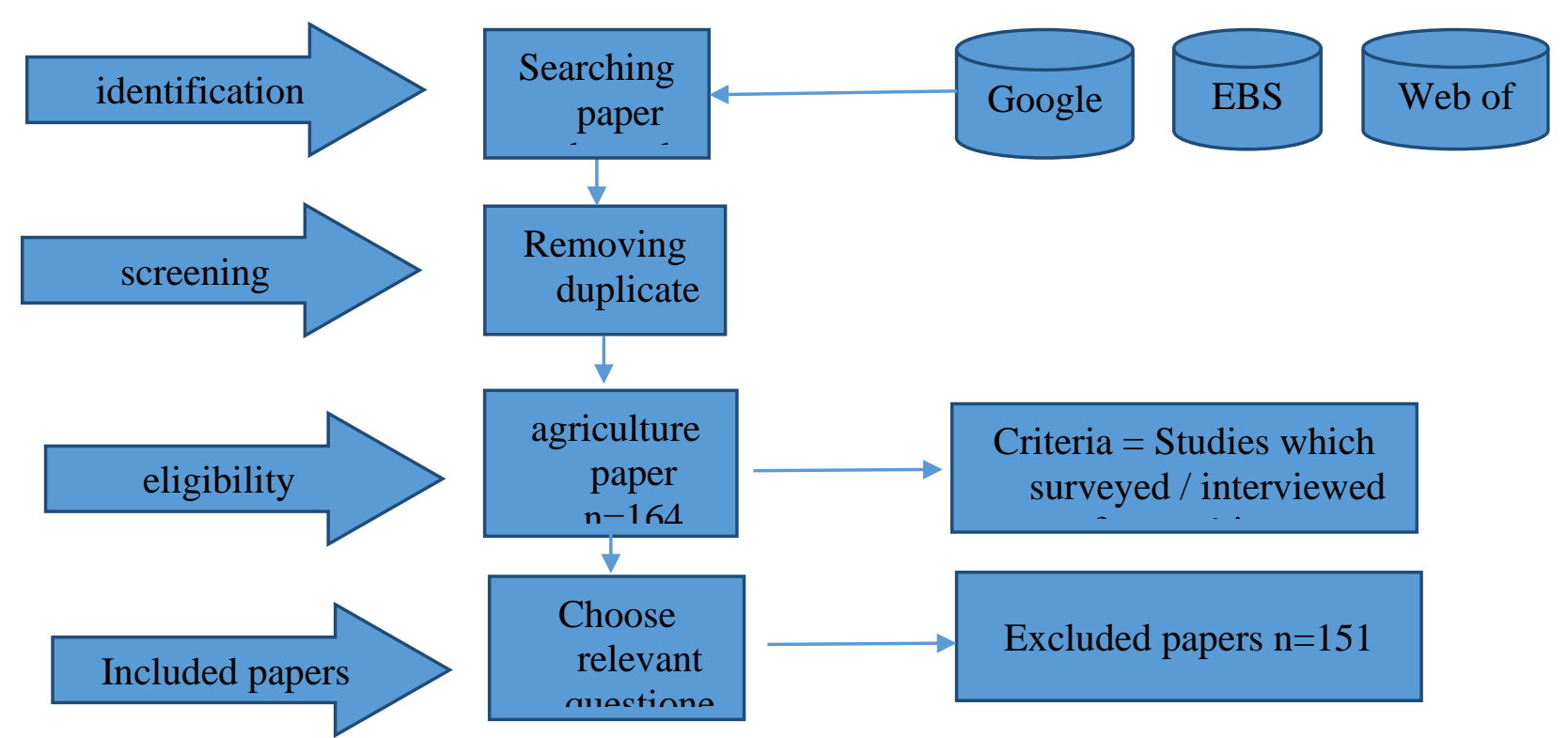

Figure 1: Selection Criteria of Studies 
Table 1

List of Selected Article used for Analysis

\begin{tabular}{|c|c|c|c|c|c|c|}
\hline Authors & year & Title & $\begin{array}{l}\text { Serial } \\
\text { no }\end{array}$ & Journal & Respondents & $\begin{array}{l}\text { HEC } \\
\text { Rank }\end{array}$ \\
\hline $\begin{array}{l}\text { Naeem Ahmed, Dr. } \\
\text { Muhammad Tahir } \\
\text { Mansoori, } \\
\text { Atiquzzafar Khan }\end{array}$ & 2018 & $\begin{array}{l}\text { Exploring the Scope and } \\
\text { Socio-Economic Benefits of } \\
\text { Bay' Salam for the Agriculture } \\
\text { Sector in Pakistan }\end{array}$ & P1 & $\begin{array}{l}\text { Islamic } \\
\text { banking and } \\
\text { Finance } \\
\text { Review }\end{array}$ & 40 & $\mathrm{Y}$ \\
\hline $\begin{array}{l}\text { Maria Shabir, Kashif } \\
\text { Amin, rwis } \\
\text { Muhammad, Junaid } \\
\text { Ahmad }\end{array}$ & 2020 & $\begin{array}{l}\text { Impact of Agricultural Credit } \\
\text { on Cereal } \\
\text { Productivity: Case Study of } \\
\text { District Sargodha, Punjab } \\
\text { Pakistan }\end{array}$ & $\mathrm{P} 2$ & $\begin{array}{l}\text { Theoretical } \\
\text { Economics } \\
\text { Letters }\end{array}$ & 160 & \\
\hline $\begin{array}{l}\text { Muhammad Taimoor } \\
\text { Hassan, M. Atif } \\
\text { Sattar, M. Adnan } \\
\text { Tousif, } \\
\text { Nasir, Nukhba } \\
\text { Sadiq, } \\
\text { Yasmeen }\end{array}$ & 2012 & $\begin{array}{l}\text { Role of Islamic Banking in } \\
\text { Agriculture Development in } \\
\text { Bahawalpur, Pakistan }\end{array}$ & P3 & $\begin{array}{l}\text { International } \\
\text { Journal of } \\
\text { Learning \& } \\
\text { Development }\end{array}$ & 120 & \\
\hline $\begin{array}{l}\text { Abbas Ali Chandio, } \\
\text { Yuansheng Jiang, } \\
\text { Feng Wei, Xu } \\
\text { Guangshun }\end{array}$ & 2018 & $\begin{array}{l}\text { Effects of agricultural credit on } \\
\text { wheat productivity of small } \\
\text { farms in Sindh, Pakistan Are } \\
\text { short-term loans better? }\end{array}$ & P4 & $\begin{array}{l}\text { Agricultural } \\
\text { Finance } \\
\text { Review }\end{array}$ & 180 & $x$ \\
\hline $\begin{array}{lr}\text { Nida } & \text { Akram, } \\
\text { Muhammad } & \text { Waqar } \\
\text { Akram, } & \text { Wang } \\
\text { Hongshu } & \end{array}$ & 2020 & $\begin{array}{l}\text { Study on the Socioeconomic } \\
\text { Factors Affecting Adoption of } \\
\text { Agricultural Machinery }\end{array}$ & P5 & $\begin{array}{l}\text { Journal of } \\
\text { Economics } \\
\text { and } \\
\text { Sustainable } \\
\text { Development }\end{array}$ & 305 & \\
\hline $\begin{array}{l}\text { Fakhar Imam, Allah } \\
\text { Bakhsh }\end{array}$ & 2020 & $\begin{array}{l}\text { The impact of psychological } \\
\text { factors on productivity of } \\
\text { agricultural financing: an } \\
\text { evidence from Punjab, } \\
\text { Pakistan }\end{array}$ & P6 & $\begin{array}{l}\text { Journal of } \\
\text { Economic } \\
\text { Impact }\end{array}$ & 400 & $\mathrm{Y}$ \\
\hline $\begin{array}{l}\text { Owais Shafique, Rana } \\
\text { M. Naeem Khan }\end{array}$ & 2020 & $\begin{array}{l}\text { An Empirical Study on the } \\
\text { Impact of Micro-Credit } \\
\text { Financing on the Socio- } \\
\text { Economic Status of Small } \\
\text { Agriculturists in Pakistan }\end{array}$ & P7 & $\begin{array}{l}\text { Journal of } \\
\text { Business and } \\
\text { Social Review } \\
\text { in Emerging } \\
\text { Economies }\end{array}$ & 693 & Y \\
\hline $\begin{array}{lr}\text { Abbas Ali } & \text { Chandio, } \\
\text { Yuansheng } & \text { Jiang, } \\
\text { Abdul } & \text { Rehman, } \\
\text { Martinson } & \text { Ankrah } \\
\text { Twumasi, Amber Gul } \\
\text { Pathan, Muhammad } \\
\text { Mohsin }\end{array}$ & 2020 & $\begin{array}{l}\text { Determinants of demand for } \\
\text { credit by smallholder farmers': } \\
\text { a farm level analysis based on } \\
\text { survey in Sindh, Pakistan }\end{array}$ & P8 & $\begin{array}{l}\text { Journal of } \\
\text { Asian } \\
\text { Business and } \\
\text { Economic } \\
\text { Studies }\end{array}$ & 70 & $\mathrm{Y}$ \\
\hline $\begin{array}{lr}\text { Naeem } & \text { Ahmed, } \\
\text { Atiquzzafar } & \text { Khan , } \\
\text { Muhammad } & \text { Tahir } \\
\text { Mansoori } & \end{array}$ & 2019 & $\begin{array}{l}\text { Issues in Existing Agricultural } \\
\text { Credit and Scope of Bay 'al- } \\
\text { Salam as an Alternative }\end{array}$ & P9 & $\begin{array}{l}\text { Journal of } \\
\text { Islamic } \\
\text { Business and } \\
\text { Management }\end{array}$ & 40 & $Y$ \\
\hline $\begin{array}{l}\text { Ahmad Kaleem Rana } \\
\text { Abdul Wajid }\end{array}$ & 2009 & $\begin{array}{l}\text { Application of Islamic banking } \\
\text { instrument (Bai Salam) for } \\
\text { agriculture financing in Pakistan }\end{array}$ & P10 & $\begin{array}{l}\text { British Food } \\
\text { Journal }\end{array}$ & 225 & W \\
\hline $\begin{array}{l}\text { Oliver K. Kirui, Julius } \\
\text { J. Okello, Rose A. } \\
\text { Nyikal } \\
\begin{array}{l}\text { Georgina } \\
\text { Njiraini }\end{array}\end{array}$ & 2013 & $\begin{array}{l}\text { Impact of Mobile Phone-Based } \\
\text { Money Transfer Services in } \\
\text { Agriculture: Evidence from } \\
\text { Kenya }\end{array}$ & P11 & $\begin{array}{l}\text { Quarterly } \\
\text { Journal of } \\
\text { International } \\
\text { Agriculture }\end{array}$ & 379 & \\
\hline $\begin{array}{l}\text { Mohammad Main } \\
\text { Uddin }\end{array}$ & 2008 & $\begin{array}{l}\text { Credit for the Poor: The } \\
\text { Experience of Rural } \\
\text { Development Scheme of Islami } \\
\text { Bank Bangladesh Ltd. }\end{array}$ & P12 & $\begin{array}{l}\text { The Journal of } \\
\text { Nepalese } \\
\text { Business } \\
\text { Studies }\end{array}$ & 50 (Interviews) & \\
\hline $\begin{array}{l}\text { Nurul Aien Binti Abd } \\
\text { Aziz, Noreen Noor } \\
\text { Binti Abd Aziz, Yon } \\
\text { Bahiah Wan Aris, } \\
\text { Nurul Ashykin Binti } \\
\text { Abd Aziz } \\
\end{array}$ & 2015 & $\begin{array}{l}\text { Factors Influencing the Paddy } \\
\text { Farmers' Intention to } \\
\text { Participate in Agriculture } \\
\text { Takaful }\end{array}$ & P13 & $\begin{array}{l}\text { Procedia } \\
\text { Economics } \\
\text { and Finance }\end{array}$ & 120 & - \\
\hline
\end{tabular}

Like Systematic Literature Review (SLR), content analysis is the method to derive the variables from literature for developing its constructs in future studies. SLR also uses and helps within given research scope, giving directions, and informing future research ways. But comparing the thematic analysis more comprehensive and objective scope works very rule-guided fashion. Using the content analysis test or analyzes (codes), the available 
data may be visual, verbal or written form and generate themes and then test the themes after that (Faghiri et al., 2019; Lakshmi \& Corbett, 2020; Strang et al., 2021). This method explores and gauges the topic, proves the new dimensions and extends the knowledge regarding the topic and better understanding. Its uses the summarizing of the topic, identifying the research gap, and concluding the results batter ways like what issues are discussed most and what issues are discussed less.

\section{Results}

This study checks the farmers' financial issues facing in the agriculture sector and selected the relevant questionnaire-based studies. The thematic analysis is used in this study, creating the themes with the help of the coding process. The first step is to create codes and then create themes. Performing the analysis, five major themes (shown in Fig. 2 ). These are credit or financing issues, inputs issues, skills or abilities issues, land related issues and selling issues. These are divided the sixteen sub-themes. Table 2 shows the themes, definitions, and examples from the selected papers listed in Table 1.

\section{Table 2}

\section{List of all Expected Themes, Definition and Example}

\begin{tabular}{|c|c|c|}
\hline Theme & Definition & Examples \\
\hline Inputs availability & $\begin{array}{l}\text { Agriculture inputs availability is } \\
\text { defined as assurance of products } \\
\text { permitted to use in farming. It } \\
\text { includes fertilizers, pesticides, seeds } \\
\text { and their quality, and the other } \\
\text { aspects also include, like rainfall or } \\
\text { natural disasters, and labor } \\
\text { availability. }\end{array}$ & $\begin{array}{l}\text { "Observed that hiring labor or purchasing fertilizer } \\
\text { and other inputs are the main purposes of the } \\
\text { credit." (P10, p.279) }\end{array}$ \\
\hline Welfare of farmer & $\begin{array}{l}\text { Those programs that improve the } \\
\text { farmer life style, health and } \\
\text { wellbeing. }\end{array}$ & $\begin{array}{l}\text { "The authors concluded that government } \\
\text { policymaking in credit can influence household } \\
\text { incomes directly and indirectly via the input and } \\
\text { output markets as well as through improved } \\
\text { access to key facilities like health and education". } \\
\text { (P10, p.279) }\end{array}$ \\
\hline Education of farmer & $\begin{array}{l}\text { Education which aware the farmers } \\
\text { about weather, seeds, new methods } \\
\text { of cultivation and knowledge that } \\
\text { how can they get more outputs and } \\
\text { also they should have knowledge } \\
\text { about financing facilities and market } \\
\text { knowledge. }\end{array}$ & $\begin{array}{l}\text { "Etonihu et al. (2013) reported that the formal } \\
\text { education, distance to formal financial institutions } \\
\text { and types of credit source were significant factors } \\
\text { prompting smallholders' accessibility to credit in } \\
\text { Nigeria," (P8, p.5) }\end{array}$ \\
\hline $\begin{array}{l}\text { Agricultural } \\
\text { machinery }\end{array}$ & $\begin{array}{l}\text { Agricultural machinery is mechanical } \\
\text { structures and equipment that used } \\
\text { in farming or agriculture. The } \\
\text { example includes hand tools and } \\
\text { power tools for tractors and several } \\
\text { farm implements that they tow or } \\
\text { operate. }\end{array}$ & $\begin{array}{l}\text { "Basically loans are provided to farmers for } \\
\text { purchase of fixed assets like machinery, } \\
\text { equipment vans and tractors etc". (P3, p.126) } \\
\text { "The Government of Pakistan (GOP) encourages } \\
\text { the farm mechanization to improve per hectare } \\
\text { yield and overwhelm food security challenges." } \\
\text { (P5, p.69) }\end{array}$ \\
\hline Availability of labor & $\begin{array}{l}\text { Funding labor or workforce costs in } \\
\text { agriculture activities. }\end{array}$ & $\begin{array}{l}\text { However, in the meantime, increasing of rural- } \\
\text { urban migration and development of off farm work } \\
\text { activities are reason of seasonal labor shortage } \\
\text { (Zhang et al., 2014). (P5, p.68) }\end{array}$ \\
\hline Access to finance & $\begin{array}{l}\text { Individual ability to take finance for } \\
\text { agriculture activities and provide } \\
\text { collateral and other sufficient } \\
\text { guarantees to obtain finance }\end{array}$ & $\begin{array}{l}\text { "Poor farmers need credit but generally they face } \\
\text { severe difficulties in accessing it". (P1, p. 40) }\end{array}$ \\
\hline Limited size of land & $\begin{array}{l}\text { The available land used for } \\
\text { cultivation or farming activities which } \\
\text { has high cost of extension. }\end{array}$ & $\begin{array}{l}\text { "Most of the farmers have small farm holdings in } \\
\text { the rural areas of Pakistan. The net area for } \\
\text { cultivation per dependent on agricultural is } \\
\text { relatively low and is around } 58 \% \text { of farm size of } \\
\text { less than } 5 \text { acres." (P8, p. } 3 \text { ) }\end{array}$ \\
\hline Cost of production & $\begin{array}{l}\text { The expenses to grow the crops, } \\
\text { including high prices of inputs or } \\
\text { financing rates. }\end{array}$ & $\begin{array}{l}\text { "Credit plays a significant role in the farming } \\
\text { sector. Therefore, the timely and easy access of } \\
\text { agricultural credit is the quickest way to increase } \\
\text { wheat productivity. Additionally, } 38 \text { respondents } \\
\text { ( } 21.1 \text { percent) complained about the high interest } \\
\text { rate charged by financial institutions". (P4, p.605) }\end{array}$ \\
\hline $\begin{array}{l}\text { Fertilizer } \\
\text { availability/Quality }\end{array}$ & $\begin{array}{l}\text { Ease of access to chemicals which } \\
\text { increase the farm fertility and yield. }\end{array}$ & $\begin{array}{l}\text { "The improvement in the agricultural production } \\
\text { cannot be derived without adoption of modern } \\
\text { technology and inputs." (P8, p.1) }\end{array}$ \\
\hline
\end{tabular}


Middleman / Broker exploitation

Riba

Quality of input

Water

What to grow

Access to Market

Pricing

Technology
The agent who buys crop from the farmer on low price and earns from sale or from providing informal finance and inputs to the farmer at more than market price to exploited the farmer.

Its concept in Islam that refers to charging interest. It is denoted as usury, or asking fixed returns without bearing risk.

The assurance of a good quality of products permitted to use in farming. Its includes fertilizers, pesticides, and seeds.

The major source of growing the crops is irrigation facilities. The major sources of water are include tube well facilities, canals and other irrigation sources.

The process of preparing the land for cultivation and basic requirements or facilities are available for the cultivation process like electricity or fuel availability.
"Salam has proved itself as a useful mode of finance since farmers are rid of exploitation and are able to earn profit. They are able to feed their families in a better way, purchase inputs at cheaper rates and get rid of undue pressures from the middleman, shopkeepers and input suppliers". (P1, p.55)

"Siddiqi (2005) says that throughout Islamic history interest was prohibited both on consumption and production loans". (P1, p.46)

"Organic fertilizers replaced by the chemical or synthetic fertilizers contain nitrogen, phosphorus and potassium because through these fertilizers metabolic reaction takes improved soil potential growth, improved quality of seed and increase quantity of food (Romanowski, 1997)" (P3, p.125) "Salam financing is also useful in long term for gardens, tube wells and purchase of machinery. It is beneficial as it provides long term investment opportunities (Hasanuzzaman, 1984)" (P1, p.45) "For agriculture activity on additional surface irrigation depend on the average annual rainfall is less than 100 $-300 \mathrm{~mm}$ rang per year in the projected area (Middlebrook, Mustafa, \& Flower, 2007)" (P3, p.124)

"Different crops need different type of drills, for example, conventional tillage specially uses for wheat to reduce distance and depth issues and must take time to prepare land for seed drilling. (Younis, Sabir, Iqbal, \& Alit, 2006)". (P5, p.70) "Bashir et al. (2010) examined the impact of credit on wheat productivity by using Cobb-

Douglas production function and concluded that the impact of agricultural credit comes through using more wheat seeds per acre, more fertilizers and pesticides per acre, better irrigation and more efficient land preparation." (P4, p593)

"Khandker et al. (2006) in case of Bangladesh found that the road project lowered agriculture input cost, increased transportation demand and hence increased farm productivity." (P10, p.279) "Sometimes reimburse their money late; 19.25 percent farmers complain that that their payments are always delayed. Further, 33.8 percent of the total respondents comment that once you sell your crop, it is difficult to recover money" (P10, p.283)

"Fastest agriculture growth depends on the technological changes. Technical efficiency, inputs improvements, funds and better infrastructure and farmer capabilities are revolution factors in agriculture achieved by the technological changes (Evenson, 2002)" (P3, p.125)

Table 3 provides the frequencies of the identified themes. Firstly, the issues discussed across most of the selected papers are access to finance and input availability. The most quoted issue based on the frequency of its code is the riba involved in the current form of financing. Certainty finance can fulfil its purpose in production when it is readily available and cost-effective for farmers. Further, though output generation depends on crop gestation periods, labour compensations are more frequent, so efficient production highly depends on timely availability to finance timely periodical (monthly) compensation for the labour. Now, while discussing the study, which covered most of the themes, paper 5 (Akram et al., 2020) encompasses all themes, from which the most prominent one is the availability of agricultural machinery as the most discussed issue faced by farmers. In a developing country like Pakistan, farmers look for the rental acquisition of the agricultural machinery, which requires funds to finance it before the receipts of agricultural output sale.

In order to validate the finding, the reliability analysis is conducted using the interclass correlation coefficient (ICC). For this, $20 \%$ of data was given to the second independent rater with all the details of themes, definitions and examples (from table 1). 
The second-rater person created the coded file and executed the ICC. All of the themes' ICC is more than 0.60 , shown in table 4 , which confirms the validity of the scoring of themes.

\section{Table 3}

\section{Frequency of Themes in Selected Studies}

\begin{tabular}{|c|c|c|c|c|c|c|c|c|c|c|c|c|c|c|}
\hline Themes & Sub Themes & P1 & P2 & P3 & P4 & P5 & P6 & P7 & P8 & P9 & P10 & P11 & P12 & P13 \\
\hline $\begin{array}{l}\text { Credit/ } \\
\text { Finance }\end{array}$ & Access to finance & 8 & 3 & 6 & 16 & 7 & 5 & 7 & 10 & 5 & 9 & 3 & & 1 \\
\hline \multirow{3}{*}{$\begin{array}{l}\text { Interest- } \\
\text { rate }\end{array}$} & Cost of production & 1 & & 1 & 6 & 3 & & 1 & 1 & & 1 & 3 & & \\
\hline & $\begin{array}{l}\text { Middleman /Broker } \\
\text { exploitation }\end{array}$ & 8 & & & 1 & 2 & & & & 4 & 9 & & & \\
\hline & Riba & 18 & & 2 & 2 & 1 & & & 4 & 8 & 5 & & & \\
\hline \multirow[t]{4}{*}{ Inputs } & Machinery & 2 & & 4 & 5 & 14 & 1 & & & & 2 & & & \\
\hline & $\begin{array}{l}\text { Availability of } \\
\text { labor }\end{array}$ & & & 1 & 3 & 8 & 1 & 1 & & & 1 & 1 & & 1 \\
\hline & Quality of fertilizer & 3 & 3 & 7 & 15 & 1 & 4 & 2 & 3 & 1 & 4 & 1 & & \\
\hline & $\begin{array}{l}\text { Availability inputs } \\
\text { and climate }\end{array}$ & 2 & 3 & 6 & 14 & 1 & 4 & 2 & 3 & 2 & 7 & 1 & & 3 \\
\hline \multirow[t]{3}{*}{ Skills/Ability } & Welfare of farmer & 6 & 2 & 2 & 4 & 2 & 1 & 4 & 3 & & 1 & 1 & & 1 \\
\hline & $\begin{array}{l}\text { Education of } \\
\text { farmer }\end{array}$ & & & 1 & & 2 & & 2 & 5 & & 2 & & 2 & 1 \\
\hline & Technology & & 1 & 9 & 3 & 3 & 3 & 2 & 4 & & 1 & 10 & 2 & \\
\hline \multirow{3}{*}{$\begin{array}{l}\text { Other } \\
\text { Problems }\end{array}$} & Water & 2 & 1 & 12 & 4 & 8 & 2 & & 1 & & 1 & & & \\
\hline & $\begin{array}{l}\text { What to grow/ } \\
\text { Preparation land, } \\
\text { Electricity etc. }\end{array}$ & 2 & 2 & 1 & 6 & 5 & & & 1 & & & & & \\
\hline & $\begin{array}{l}\text { Limited size of } \\
\text { land }\end{array}$ & 1 & & & 6 & 5 & 2 & & 5 & & & & 1 & \\
\hline \multirow[t]{2}{*}{ Selling } & Access to market & 1 & & 2 & & 3 & & & 4 & & 5 & & & \\
\hline & Price & 2 & & 2 & & 1 & & & & & 4 & & & 1 \\
\hline
\end{tabular}

Table 4

\section{ICC Test}

\begin{tabular}{lccccc}
\hline Theme & ICC & Lower Bound & Upper Bound & Value & Significance \\
\hline Access to finance & 0.671 & 0.451 & 0.829 & 5.077 & $0.00^{*}$ \\
Cost of production & 0.728 & 0.503 & 0.861 & 6.357 & $0.00^{*}$ \\
Middle man exploitation & 0.728 & 0.503 & 0.861 & 6.357 & $0.00^{*}$ \\
Riba & 0.611 & 0.327 & 0.794 & 4.146 & $0.00^{*}$ \\
Machinery & 0.841 & 0.693 & 0.921 & 11.574 & $0.00^{*}$ \\
Agriculture labor & 0.841 & 0.693 & 0.921 & 11.574 & $0.00^{*}$ \\
Fertilizer quality & 0.841 & 0.693 & 0.921 & 11.574 & $0.00^{*}$ \\
Inputs & 0.705 & 0.467 & 0.848 & 5.787 & $0.00^{*}$ \\
Welfare & 0.791 & 0.606 & 0.895 & 8.551 & $0.00^{*}$ \\
Education & 0.791 & 0.606 & 0.895 & 8.551 & $0.00^{*}$ \\
Technology & 0.791 & 0.606 & 0.895 & 8.551 & $0.00^{*}$ \\
Water & 0.814 & 0.645 & 0.907 & 9.738 & $0.00^{*}$ \\
What to grow & 0.766 & 0.565 & 0.881 & 7.550 & $0.00^{*}$ \\
Limited land & 0.707 & 0.470 & 0.849 & 5.823 & $0.00^{*}$ \\
Access to market & 0.707 & 0.470 & 0.849 & 5.823 & $0.00^{*}$ \\
Pricing & 0.630 & 0.354 & 0.805 & 4.400 & $0.00^{*}$ \\
\hline
\end{tabular}

* Significant at $1 \%$

\section{Conclusion and Policy Implications}

The importance of the agriculture sector is on the rise in the case of Pakistan because of its recent turmoil. No country can deny the role of the agriculture sector, as it is the source of food and employment. The conventional financial institutions are providing financing facilities to the farmers are exploitative and interest-based structures. Modernization and advancement of agriculture are not possible without financing throughout the production process. This financing can transition the traditional agriculture sector to the advanced and mechanized agriculture sector.

Currently, the interest-free schemes are scarce in terms of provision and acceptability. Islam has provided Salam financing as an alternative to conventional financing, emphasizing on the freedom from the Riba-based system and promotion of 
productivity. Many studies discuss the financial issues in the agriculture sector faced by the farmer but lacked structuring of issues to assist the Salam product developers.

The primary objective of this study is to categorize different dimensions pertaining to the under fulfilled financing needs of farmers to derive restructuring suggestions for Salam applicability in Pakistan. This study has used qualitative content analysis and collected 13 questionnaire based studies from the years 2008 to 2020. In the process of analysis made five major themes and sixteen sub-themes. The $20 \%$ of data was given to the second independent rater and thematic expert with compiled themes, definitions and examples. Rater used the interclass correlation coefficient (ICC). The results confirmed the validity of themes; all themes values of ICC are more than $60 \%$.

This study categorized the variables using the thematic analysis firstly will help in acknowledging the importance of demand and supply side forces in developing an Islamic banking financing instrument. Previously, only the financial viability from the banking side was considered, but since the Islamic bank poses itself as a trader, it must also cater to the social needs of society under the Macro Maqasid al Shari'ah (Al-Mubarak \& Osmani, 2010). Secondly, these themes could be addressed in the development of Salam financing structure to improve the effectiveness and acceptability of Salam. Hence policymakers should promote Salam as a riba free alternative. The rural area bank branches should prioritize the availability of Salam funds in a cost-effective manner while comparing the conventional counterparts. Further, for output generation and gestation period variation of crops, financing provision should include periodic labour compensations for farmers. While providing financing, the banking sector could utilize their industry linkages to bundle agricultural machinery for farmers for rental acquisition during cropping needs.

\section{References}

Abdullah, D. Z., Khan, S. A., Jebran, K., \& Ali, A. (2015). Agricultural credit in Pakistan: Past trends and future prospects. Journal of Applied Environmental and Biological Sciences, 5(12), 178-188.

Abdulquadri, A. F., \& Mohammed, B. T. (2012). The role of agricultural cooperatives in agricultural mechanization in Nigeria. World Journal of Agricultural Sciences, 8(5), 537-539.

Adams, D. W., \& Hunter, R. E. (2019). Informal finance in low-income countries. Routledge.

Ahmed, M., \& Roy, M. (1995). Bank Finance in Agriculture: Experiences of Islami Bank Bangladesh Limited. Journal of Rural Development and Administration, 27(3), 2130.

Ahmed, N., Mansoori, M. T., \& Khan, A. (2018). Exploring the Scope and Socio-Economic benefits of Bay'Salam for the Agriculture Sector in Pakistan. Islamic Banking and Finance Review, 5, 39-56.

Akram, N., Akram, M. W., \& Hongshu, W. (2020). Study on the socioeconomic factors affecting adoption of agricultural machinery. Journal of Economics and Sustainable Development, 11(3).

Al-Mubarak, T., \& Osmani, N. M. (2010). Applications of Maqasid al-Shari'ah and Maslahah in Islamic Banking practices: An analysis. International Seminar on Islamic Finance in India, 4-6.

Arshed, N., Yasmin, S., \& Gulzar, M. (2020). Islamic financing portfolio and its comparative growth potential. Islamic Banking and Finance Review, 7, 60-91.

Asmy, F. S., Roberge-Milanese, A., Rombaut, M. C., Smith, G., \& Fels, D. I. (2020). WebMoti. ICCHP 2020 Part II.

Balzani, A., \& Hanlon, A. (2020). Factors that influence farmers' views on farm animal welfare: A semi-systematic review and thematic analysis. Animals, 10(9), 1524.

Braun, V., \& Clarke, V. (2006). Using thematic analysis in psychology. Qualitative Research in Psychology, 3(2), 77-101.

Chandio, A. A., Yuansheng, J., Sahito, J. G. M., \& Larik, S. A. (2016). Impact of formal credit on agricultural output: Evidence from Pakistan. African Journal of Business Management, 10(8), 162-168.

Christensen, M., \& Knight, J. (2014). 'Nursing is no place for men'-A thematic analysis of male nursing students experiences of undergraduate nursing education. Journal of Nursing Education and Practice, 4(12), 95. 
Dhumale, R., \& Sapcanin, A. (1998). An application of Islamic banking principles to microfinance. World Bank.

Faghiri, H., Yusop, Z., Krauss, S. E., Othman, M. H., \& Mohamed, Z. (2019). Factors Influencing the dairy industry development and milk production level in Malaysia: $A$ hybrid approach of coding and theme development. Journal of Modern Trends in Business Research (IJMTBR), 2(10), 34-51.

Fahad, S., \& Wang, J. (2020). Climate change, vulnerability, and its impacts in rural Pakistan: A review. Environmental Science and Pollution Research, 27(2), 13341338.

FAO. (2019). The sate of food and agriculture. Food and Agriculture Organization. https://bit.ly/2kpn9A8

Hashmi, M. S., Kamran, M. A., Bakhsh, K., \& Bashir, M. A. (2015). Technical efficiency and its determinants in wheat production: Evidence from the Southern Punjab, Pakistan. Journal of Environmental and Agricultural Sciences, 3, 48-55.

Iftikhar, S., \& Mahmood, H. Z. (2017). Ranking and relationship of agricultural credit with food security: A district level analysis. Cogent Food \& Agriculture, 3(1), 1333242.

Iqbal, M. A., Iqbal, A., Afzal, S., Akbar, N., Abbas, R. N., \& Khan, H. Z. (2015). In Pakistan, agricultural mechanization status and future prospects. American-Eurasian Journal of Agricultural \& Environmental Sciences, 15(1), 122-128.

Iqbal, M., Ahmad, M., Abbas, K., \& Mustafa, K. (2003). The impact of institutional credit on agricultural production in Pakistan [with comments]. The Pakistan Development Review, 469-485.

Kaleem, A., \& Ahmad, S. (2016). Bankers' perception towards Bai Salam method for agriculture financing in Pakistan. In Islamic Finance (pp. 66-85). Springer.

Kaleem, A., \& Wajid, R. A. (2009). Application of Islamic banking instrument (Bai Salam) for agriculture financing in Pakistan. British Food Journal.

Khaliq, T., Hussain, N., Ali, A., Ullah, A., Ahmad, M., \& Ahmad, A. (2016). Quantification of root-shoot development and water use efficiency in autumn maize (Zea mays L.) under different irrigation strategies. J. Environ. Agric. Sci, 6, 16-22.

Khan, W., \& Nomani, A. (2021). Analysis of Islamic Finance as an Alternative Method for Agricultural Financing. Islamic Quarterly, 64(2-127).

Kirui, O. K., Okello, J. J., Nyikal, R. A., \& Njiraini, G. W. (2013). Impact of mobile phonebased money transfer services in agriculture: Evidence from Kenya. Quarterly Journal of International Agriculture, 52(892-2016-65177), 141-162.

Kumar, A., Singh, K. M., \& Sinha, S. (2010). Institutional credit to agriculture sector in India: Status, performance and determinants. Agricultural Economics Research Review, 23(2), 253-264.

Kumar, S. M. (2013). Does access to formal agricultural credit depend on caste? World Development, 43, 315-328.

Lakshmi, V., \& Corbett, J. (2020). How artificial intelligence improves agricultural productivity and sustainability: A global thematic analysis. Proceedings of the 53rd Hawaii International Conference on System Sciences.

Saeed, R., Ashraf, R. U., Zaidi, S. A. H., Lodhi, R. N., Ahmad, W., Awan, U., \& Malik, Q. U. Z. (2013). Islamic and conventional agri-financing in Pakistan. Scientific Papers Series-Management, Economic Engineering in Agriculture and Rural Development, 13(2), 357-361.

Saleem, M. A., \& Jan, F. A. (2011). The impact of agricultural credit on agricultural productivity in Dera Ismail Khan (District) Khyber Pakhtonkhawa Pakistan. European Journal of Business and Management, 3(2), 38-44.

SBP. (2017). Economic Survey Of Pakistan.

SBP. (2021). Islamic banking bulletin Aprill-June 2021. State Bank of Pakistan. https://www.sbp.org.pk/ibd/Bulletin/2021/Jun.pdf

Shabir, M., Amin, K., Muhammad, A., \& Ahmad, J. (2020). Impact of Agricultural Credit on Cereal Productivity: Case Study of District Sargodha, Punjab Pakistan. Theoretical Economics Letters, 10(3), 481-487.

Simon, K., \& Hansson, H. (2019). What are the Implications of Regulation of Acquisition of Agricultural and Forestry Land-Insights from an Analysis of Mental Models of Expert Stakeholders in Sweden using Thematic Analysis.

Sims, B., \& Kienzle, J. (2016). Making mechanization accessible to smallholder farmers in sub-Saharan Africa. Environments, 3(2), 11.

Strang, K. D., Che, F., \& Vajjhala, N. R. (2021). Thematic Analysis of Agricultural Government Policy and Operational Problems. Agricultural Research, 1-8. 
Uddin, M. N. (2008). Agricultural extension services in Bangladesh: A review study. Department of Agricultural Extension Education, Bangladesh Agricultural University, Bangladesh.

Vadlamudi, S. (2019). How Artificial Intelligence Improves Agricultural Productivity and Sustainability: A Global Thematic Analysis. Asia Pacific Journal of Energy and Environment, 6(2), 91-100.

Yazdani, S., \& Hill, G. P. (1993). Islamic credit: The Iranian experience. Journal of Agricultural Economics, 44(2), 301-310.

Zaidi, A. (2005). Issues in Pakistan's Economy. OUP Catalogue.

Zuberi, H. A. (1989). Production function, institutional credit and agricultural development in Pakistan. The Pakistan Development Review, 43-55.

\section{Appendix A}

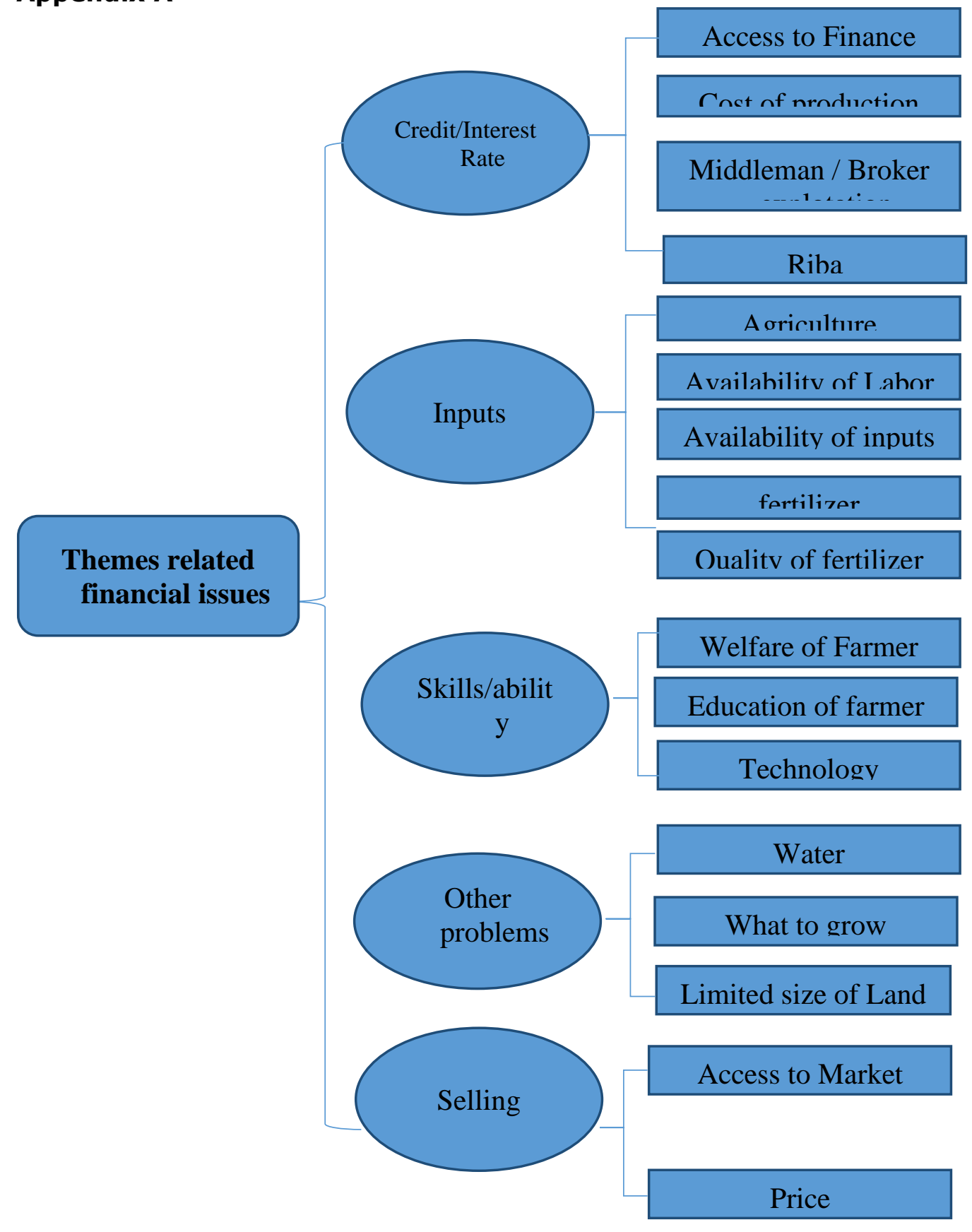

Figure 2. Expected financial issues in the agriculture sector 